\title{
Arsenate substitution in lead hydroxyl apatites: a Raman spectroscopic study
}

Alicja Giera ${ }^{a}$, Maciej Manecki ${ }^{b}{ }^{,}$, Tomasz Bajda $^{\mathrm{b}}$, John Rakovan ${ }^{\mathrm{c}}$, Monika KwaśniakKominek $^{\mathrm{b}}$, Tomasz Marchlewski ${ }^{\mathrm{C}}$

aInstitute of Geological Sciences, Polish Academy of Sciences INGPAN, ul. Senacka 1, 31-002 Kraków, Poland

${ }^{b}$ Department of Geology, Geophysics and Environmental Protection, AGH University of Science and Technology, al. Mickiewicza 30, 30-059 Kraków, Poland

${ }^{c}$ Department of Geology and Environmental Earth Science, Miami University, 114 Shideler Hall, Oxford, OH 45056, USA

*Corresponding author.Tel.: +48 604427 198. E-mail address: gpmmanec@cyf-kr.edu.pl

\section{Abstract}

A total of seven compounds of the hydroxylpyromorphite $\mathrm{Pb}_{10}\left(\mathrm{PO}_{4}\right)_{6}(\mathrm{OH})_{2}$ hydroxylmimetite $\mathrm{Pb}_{10}\left(\mathrm{AsO}_{4}\right)_{6}(\mathrm{OH})_{2}(\mathrm{HPY}-\mathrm{HMl})$ solid solution series were synthesized at $80^{\circ} \mathrm{C}$ from aqueous solutions and characterized using Raman spectroscopy. The positions of the bands in all spectra of the series depend on the content of arsenates and phosphates shifting to lower wavenumbers with substitution of $\left(\mathrm{AsO}_{4}\right)^{3-}$ for $\left(\mathrm{PO}_{4}\right)^{3-}$. This shift results from the decreasing bond strength of $X-O$ (where $X=P, A s$ ) and higher atomic mass of $\mathrm{As}$ than $\mathrm{P}$. The position and intensity of major $\left(\mathrm{PO}_{4}\right)^{3-}$ and $\left(\mathrm{AsO}_{4}\right)^{3-}$ bands in Raman spectra exhibit linear correlation with As content, while the ratio of the intensities of these peaks shows exponential correlation. This results due to different polarizability of $\left(\mathrm{PO}_{4}\right)^{3-}$ and $\left(\mathrm{AsO}_{4}\right)^{3-}$ molecules. A small carbonate band develops with increasing As content indicating that hydroxyl lead apatites adopt the $\left(\mathrm{CO}_{3}\right)^{2-}$ ions, particularly at the arsenate end of the series.

\section{Graphical abstract}

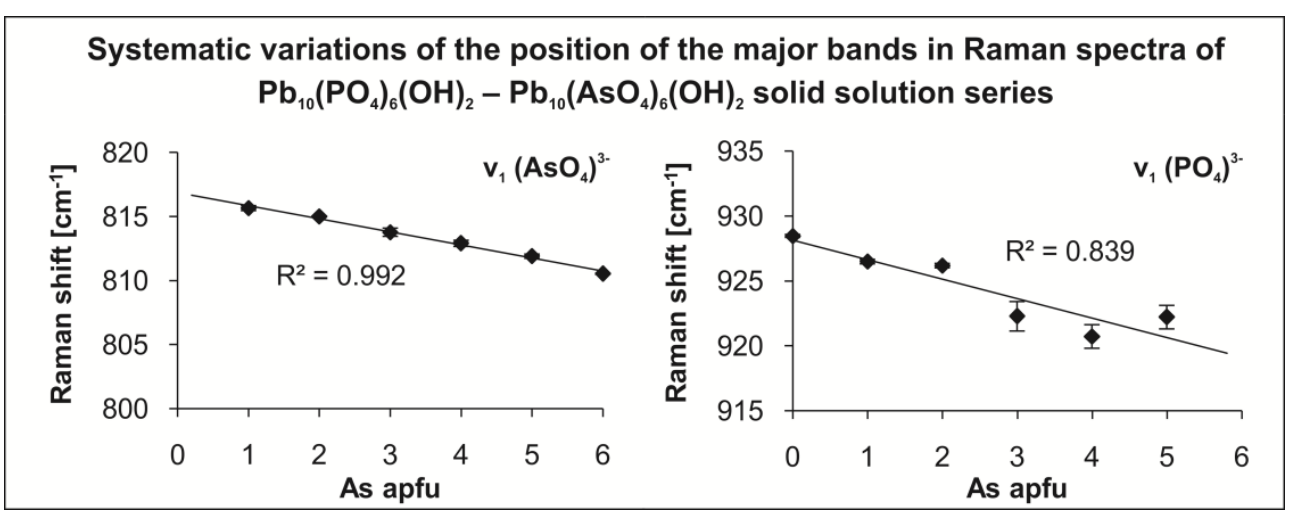




\section{Keywords}

pyromorphite, mimetite, solid solution, lead apatite, carbonate in apatites, Raman band shift

\section{Introduction}

Lead apatites are recently intensively studied due to their significance in the environmental cycle of $\mathrm{Pb}$ and As [1-11]. Existing data related to lead hydroxyl apatites with arsenate substitution - forming hydroxyl analogs of pyromorphite-mimetite series are rather superficial and outdated. Moreover, they focus mostly on lattice parameters and IR studies of end members [12-15]. Solid solutions have been examined so far in terms of $\mathrm{pH}$ dependence of their solubility, lattice constants as well as preliminary IR spectroscopic study [16-17]. Selected physicochemical studies of $\mathrm{Pb}_{10}\left(\mathrm{PO}_{4}\right)_{6}(\mathrm{OH})_{2}$ may also be found in the sources concerning $\mathrm{Ca}-\mathrm{Pb}$ substitution in hydroxyl apatites [18-19].

Apatites can accommodate numerous substitutions, both cationic and anionic. Apatite is expressed by a general formula $\mathrm{Me}_{10}\left(\mathrm{TO}_{4}\right)_{6}(\mathrm{X})_{2}$, where $\mathrm{Me}$ are divalent cations distributed on two distinct crystallographic sites (e.g., $\mathrm{Ca}^{2+}$ or $\mathrm{Pb}^{2+}$ ), $\mathrm{TO}_{4}$ is a trivalent oxyanion (e.g., $\mathrm{PO}_{4}{ }^{3-}, \mathrm{AsO}_{4}{ }^{3-}$ ), and $\mathrm{X}$ is a monovalent anion (dominated by $\mathrm{OH}^{-}, \mathrm{F}^{-}, \mathrm{Cl}^{-}$), divalent anion (e.g. $\mathrm{O}^{2-}, \mathrm{CO}_{3}{ }^{2-}$ ) or a vacancy [20-22]. Many mineral compounds crystallizing with the apatite structure are frequently discussed and reviewed in the literature on biomaterials, mineralogy, geology, environmental studies, and material science and technology, etc. [23]. However, the terms "hydroxylpyromorphite" and "hydroxylmimetite" have not yet been approved as the mineral names of $\mathrm{Pb}_{10}\left(\mathrm{PO}_{4}\right)_{6}(\mathrm{OH})_{2}$ and $\mathrm{Pb}_{10}\left(\mathrm{AsO}_{4}\right)_{6}(\mathrm{OH})_{2}$ by the International Mineralogical Association. The occurrence of these phases in natural environment has been indicated to date only by fragmentary 
analyses of near end-members: OH-rich pyromorphite was found in Hares Valley (Pennsylvania, USA) by X-ray diffraction spectroscopy [24], while the presence of halogendeficient mimetite in the Schwarzwald mining district (Germany) was suggested on the basis of electron microprobe analyses [25].

In vibrational spectroscopic study of Cl-varieties of lead apatites (pyromorphitemimetite series), Bajda et al. [26] demonstrated systematic changes of peak positions and intensities in spectra of phases with different content of phosphates and arsenates. A strong correlation between the positions of the selected vibrational modes and the As/(As $+\mathrm{P})$ ratio was revealed. The research on arsenate substitution in lead hydroxyl apatites using that analytical method was conducted due to two main reasons: successful application of Raman spectroscopy for nondestructive analysis of the pyromorphitemimetite series and lack of Raman data on their hydroxyl analogs. The current work is based on the assumption that in the case of hydroxyl analogs of pyromorphite-mimetite series (HPY-HMI), similar correlations can be observed. Seven synthetic crystalline powders with increasing As content were examined by Raman spectroscopy. Interpretation of raw Raman spectra followed by peak resolve operation in selected regions is presented indicating that systematic shifts in Raman spectra may be used for semiquantitative estimation of As content in lead apatites from this series. This extends the applications of Raman spectroscopy for environmental problems.

\section{Experimental Procedure}

The procedure of the synthesis and characteristics of the research material (e.g. morphology, chemical composition and XRD patterns and crystal lattice parameters) are presented elsewhere [27]. Briefly, the samples were precipitated from aqueous solutions in computer-controlled chemistate (Metrohm 846 dosing interface) by mixing $0.05 \mathrm{M}$ $\mathrm{Pb}\left(\mathrm{NO}_{3}\right)_{2}$ and a $0.03 \mathrm{M}$ mixture of $\mathrm{KH}_{2} \mathrm{AsO}_{4}$ and $\mathrm{KH}_{2} \mathrm{PO}_{4}$ at $\mathrm{pH} 8(\mathrm{KOH})$ and $80^{\circ} \mathrm{C}$. The assumed composition of the final products was $\mathrm{Pb}_{10}\left[\left(\mathrm{PO}_{4}\right)_{6-x}\left(\mathrm{AsO}_{4}\right)_{\mathrm{x}}\right](\mathrm{OH})_{2}$, where $\mathrm{x}=0$, $1,2,3,4,5,6$. The syntheses yielded white, homogeneous, crystalline precipitates, identified with XRD and SEM-EDS as HPY-HMI solid solutions. The precipitates consist of hexagonal rods and prisms. Bimodal size distribution is observed: the average size of coarser crystals is $4 \mu \mathrm{m}$, while the size of the smaller ones is below $1 \mu \mathrm{m}$. This is probably a result of Ostwald ripening during aging [27]. In addition to the EDS data presented therein, the composition of the synthetic phases was determined by wet chemical analysis. An aliquot of $100 \mathrm{mg}$ of solid was digested in $50 \mathrm{~mL} 0.02$ EDTA and analyzed for Pb and 
As by atomic absorption spectroscopy (AAS) and for $P$ using UV-Vis spectrophotometry (after reduction of $\mathrm{As}(\mathrm{V})$ to $\mathrm{As}(\mathrm{III})$ to avoid the interference).

The Raman spectra were recorded at room temperature using a DXR Raman microscope (Thermo Scientific). Approximately $0.5 \mathrm{~g}$ of dry crystalline powder sample was placed on a glass slide and analyzed with a green laser $(\lambda=532 \mathrm{~nm}$, laser power of $5 \mathrm{~mW}$, slit aperture of $25 \mu \mathrm{m}$, resolution of $1.9 \mathrm{~cm}^{-1}$ in the range between 100.6 and $3579.6 \mathrm{~cm}^{-1}$ ). A total of 10 exposures of 3 seconds were taken for each spectrum. To minimize any possible anisotropy effect on the intensity resulting from random crystallographic orientation of analyzed grains [28] and to avoid sample thickness effect, the analysis of each specimen was repeated 4 times on various grains. Interpretation of spectra was performed with the aid of OMNIC for Dispersive Raman software. Each collected spectrum was processed separately and the averaged results are presented.

\section{Results and discussion}

The results of wet chemical analysis presented in Table 1 are in accordance with the intended composition of products of synthesis as well as with the EDS data [27]. Observed small deviations from stoichiometry result from limitations of applied analytical methods and calculations [8] $(\mathrm{OH}$ content is assumed based on ideal formula, potential presence of carbonate ion is not considered). A good agreement between the solution composition and the resulting precipitate is commonly observed for synthetic solid solutions of apatites precipitated from aqueous solutions [e.g. 29-31 and the literature cited therein]. The mechanisms causing nonstoichiometry of cationic substitution observed by Jambor \& Dutrizac [32] do not apply here. The adoption of modified synthesis procedure presented by Flis et al. [29] results in precipitation of expected phases.

Table 1 Results of wet chemical analysis of the synthetic HPY-HMI series

\begin{tabular}{|c|c|c|c|}
\hline \multicolumn{2}{|c|}{ Intended sample composition } & \multicolumn{2}{|c|}{ Sample composition by wet chemical analysis } \\
\hline Chemical formula & $\mathrm{Pb} /(\mathrm{As}+\mathrm{P})$ ratio & Chemical formula & $\mathrm{Pb} /(\mathrm{As}+\mathrm{P})$ ratio \\
\hline $\mathrm{Pb}_{10}\left(\mathrm{PO}_{4}\right)_{6}(\mathrm{OH})_{2}$ & & $\mathrm{~Pb}_{10}\left(\mathrm{PO}_{4}\right)_{5.66}(\mathrm{OH})_{2}^{*}$ & 1.77 \\
\hline $\mathrm{Pb}_{10}\left[\left(\mathrm{PO}_{4}\right)_{5}\left(\mathrm{AsO}_{4}\right)\right](\mathrm{OH})_{2}$ & & $\mathrm{~Pb}_{10}\left[\left(\mathrm{PO}_{4}\right)_{5.04}\left(\mathrm{AsO}_{4}\right)_{0.97}\right](\mathrm{OH})_{2}$ & 1.66 \\
\hline $\mathrm{Pb}_{10}\left[\left(\mathrm{PO}_{4}\right)_{4}\left(\mathrm{AsO}_{4}\right)_{2}\right](\mathrm{OH})_{2}$ & & $\mathrm{~Pb}_{10}\left[\left(\mathrm{PO}_{4}\right)_{3.89}\left(\mathrm{AsO}_{4}\right)_{1.94}\right](\mathrm{OH})_{2}$ & 1.72 \\
\hline $\mathrm{Pb}_{10}\left[\left(\mathrm{PO}_{4}\right)_{3}\left(\mathrm{AsO}_{4}\right)_{3}\right](\mathrm{OH})_{2}$ & 1.67 & $\mathrm{~Pb}_{10}\left[\left(\mathrm{PO}_{4}\right)_{2.83}\left(\mathrm{AsO}_{4}\right)_{3.07}\right](\mathrm{OH})_{2}$ & 1.69 \\
\hline $\mathrm{Pb}_{10}\left[\left(\mathrm{PO}_{4}\right)_{2}\left(\mathrm{AsO}_{4}\right)_{4}\right](\mathrm{OH})_{2}$ & & $\mathrm{~Pb}_{10}\left[\left(\mathrm{PO}_{4}\right)_{1.95}\left(\mathrm{AsO}_{4}\right)_{4.03}\right](\mathrm{OH})_{2}$ & 1.67 \\
\hline $\mathrm{Pb}_{10}\left[\left(\mathrm{PO}_{4}\right)\left(\mathrm{AsO}_{4}\right)_{5}\right](\mathrm{OH})_{2}$ & & $\mathrm{~Pb}_{10}\left[\left(\mathrm{PO}_{4}\right)_{0.99}\left(\mathrm{AsO}_{4}\right)_{5.01}\right](\mathrm{OH})_{2}$ & 1.67 \\
\hline $\mathrm{Pb}_{10}\left(\mathrm{AsO}_{4}\right)_{6}(\mathrm{OH})_{2}$ & & $\mathrm{~Pb}_{10}\left(\mathrm{AsO}_{4}\right)_{5.58}(\mathrm{OH})_{2}$ & 1.79 \\
\hline
\end{tabular}

${ }^{*} \mathrm{OH}$ ions assumed on ideal formula of phases 
The internal vibrations of the free undistorted tetrahedral ions $\left(\mathrm{XO}_{4}\right)$ are generally divided into four types. For the isolated $\left(\mathrm{PO}_{4}\right)^{3-}$ ion, the position of nondegenerate symmetric stretching vibration $\mathrm{v}_{1}$ of the $\mathrm{P}-\mathrm{O}$ bond is observed at $938 \mathrm{~cm}^{-1}$, while the triply degenerate antisymmetric stretching vibration $v_{3}$ is observed at $1017 \mathrm{~cm}^{-1}$. The positions of the $\mathrm{O}-\mathrm{P}-\mathrm{O}$ angle deformation vibrations $\mathrm{v}_{2}$ (doubly degenerate) and $\mathrm{v}_{4}$ (triply degenerate) are at 420 and $567 \mathrm{~cm}^{-1}$, respectively. For the free $\left(\mathrm{AsO}_{4}\right)^{3-}$ ion, the position of $v_{1}$ mode coincides with the position of $v_{3}$ vibration at $810 \mathrm{~cm}^{-1}$. The bending vibration $v_{2}$ of O-As-O angle is observed at $342 \mathrm{~cm}^{-1}$, while the $v_{4}$ vibration is observed at $398 \mathrm{~cm}^{-1}$ [33].

The symmetry of a molecule in crystal structure is usually lower than in the isolated state owing to intermolecular interactions. This may cause splitting of the degenerate vibrations [34]. Such splitting is observed in Raman spectra of HPY-HMI solid solution series. A representative of composite spectrum of $\mathrm{Pb}_{10}\left[\left(\mathrm{PO}_{4}\right)_{5}\left(\mathrm{AsO}_{4}\right)\right](\mathrm{OH})_{2}$ with relevant band assignment is presented in Figure 1. The internal vibrations of $\left(\mathrm{PO}_{4}\right)^{3-}$ and $\left(\mathrm{AsO}_{4}\right)^{3-}$ molecules are observed in the range between 290 and $3579.6 \mathrm{~cm}^{-1}$. Coupling between the $v_{1}$ and $v_{3}$ vibrations as well as between $v_{2}$ and $v_{4}$ vibrations, noted previously on $\mathrm{Cl}$ pyromorphite and $\mathrm{Cl}$-mimetite spectra [26, 35-39], is also evident for their hydroxyl analogs. A weak band corresponding to the vibrations of $(\mathrm{OH})^{-}$ions is apparent near the upper limit of the spectra. The external (lattice) vibrations occur at low frequencies (below $\left.290 \mathrm{~cm}^{-1}\right)$. They include the librational modes of $\left(\mathrm{PO}_{4}\right)^{3-}$ and $\left(\mathrm{AsO}_{4}\right)^{3-}$ ions as well as translational modes of $\mathrm{Pb}^{2+},\left(\mathrm{PO}_{4}\right)^{3-}$, and $\left(\mathrm{AsO}_{4}\right)^{3-}[37]$.

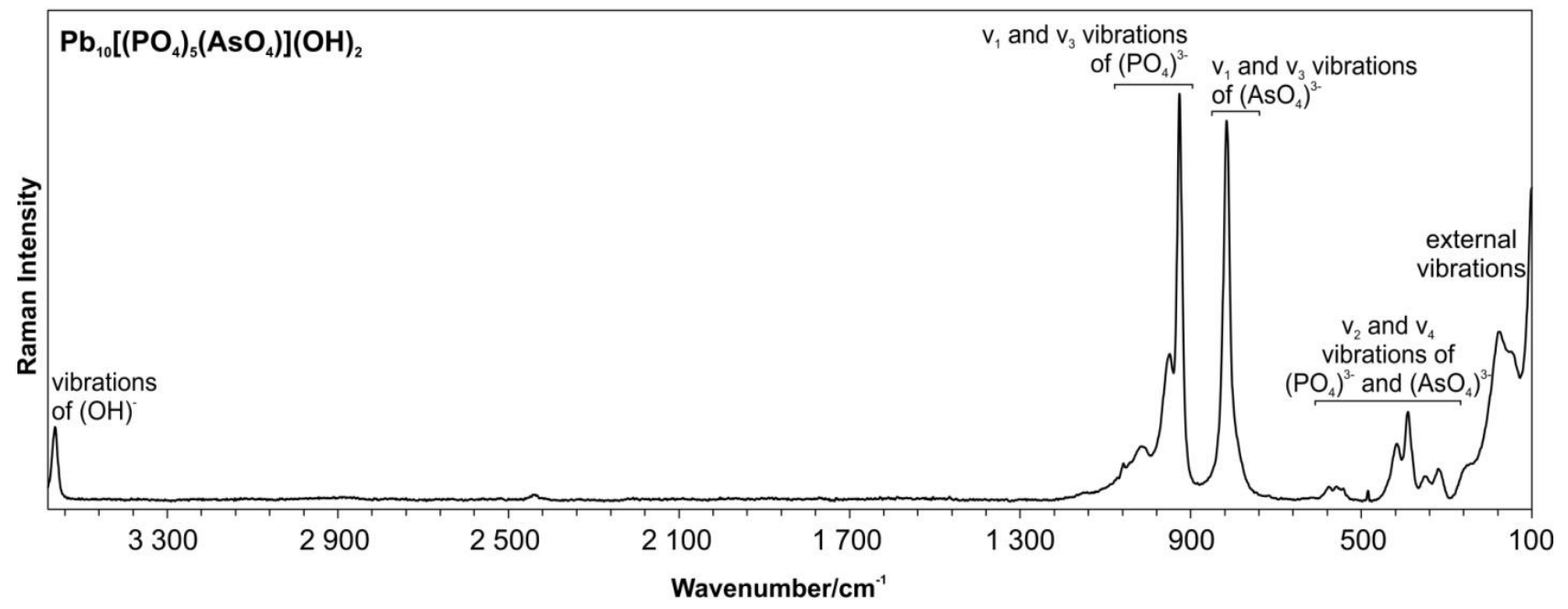

Fig. 1 Full range of Raman spectrum of synthetic $\mathrm{Pb}_{10}\left[\left(\mathrm{PO}_{4}\right)_{5}\left(\mathrm{AsO}_{4}\right)\right](\mathrm{OH})_{2}$ 
The average positions of Raman effects for all synthetic phases in the range between 290 and $1100 \mathrm{~cm}^{-1}$ with the assignment of the vibrational modes are presented in Figure 2. The effect of crystal field and presence of the $\mathrm{Pb}^{2+}$ and $(\mathrm{OH})^{-}$ions on symmetry of $\left(\mathrm{AsO}_{4}\right)^{3-}$ or $\left(\mathrm{PO}_{4}\right)^{3-}$ ions are apparent. The most intensive band in HPY spectrum (928 $\mathrm{cm}^{-1}$ ) corresponds to the nondegenerate symmetric $\mathrm{P}-\mathrm{O}$ stretching vibration $\mathrm{v}_{1}$, whereas the highest one in $\mathrm{HMI}$ spectrum $\left(811 \mathrm{~cm}^{-1}\right)$ may be attributed to both $\mathrm{v}_{1}$ and $\mathrm{v}_{3}$ modes of As- $\mathrm{O}$ bond. The triply degenerate As-O stretching vibration $\mathrm{v}_{3}$ is further split into two bands at 754 and $775 \mathrm{~cm}^{-1}$. The $v_{3}$ mode in the HPY Raman spectrum is apparent at 961 , 1014 , and $1026 \mathrm{~cm}^{-1}$. The bending vibrations $\mathrm{V}_{2}$ of the O-P-O angle are observed at 392 , 415 , and $425 \mathrm{~cm}^{-1}$ in HPY spectrum, while the $\mathrm{v}_{4}$ vibrations are observed at 542, 558, and $580 \mathrm{~cm}^{-1}$. The bands in HMl spectrum corresponding to the $\mathrm{v}_{2}$ vibrations are apparent at 314 and $340 \mathrm{~cm}^{-1}$, whereas those attributed to the $\mathrm{v}_{4}$ mode are apparent at 372,406 , and $424 \mathrm{~cm}^{-1}$. Due to the overlapping of the $\mathrm{v}_{4}$ vibrations of $\left(\mathrm{AsO}_{4}\right)^{3-}$ and the $\mathrm{v}_{2}$ mode of $\left(\mathrm{PO}_{4}\right)^{3-}$, the bands at $408-418 \mathrm{~cm}^{-1}$ in the spectra of intermediate members of the series were not assigned to either of them. The peak at $484-485 \mathrm{~cm}^{-1}$ is probably an artifact of impurities adsorbed on the surface: repeated washing of the selected samples with redistilled water using laboratory equipment resulted in reduction of that band. On the other hand, the peak at around $1055-1058 \mathrm{~cm}^{-1}$ was not reduced by washing. It most likely corresponds to the vibrations of $\left(\mathrm{CO}_{3}\right)^{2-}$ molecules [40]. Despite the fact that synthesis was performed at $80^{\circ} \mathrm{C}$, small amount of $\mathrm{CO}_{2}$ dissolved from the air was incorporated into the structure of analyzed phases. 


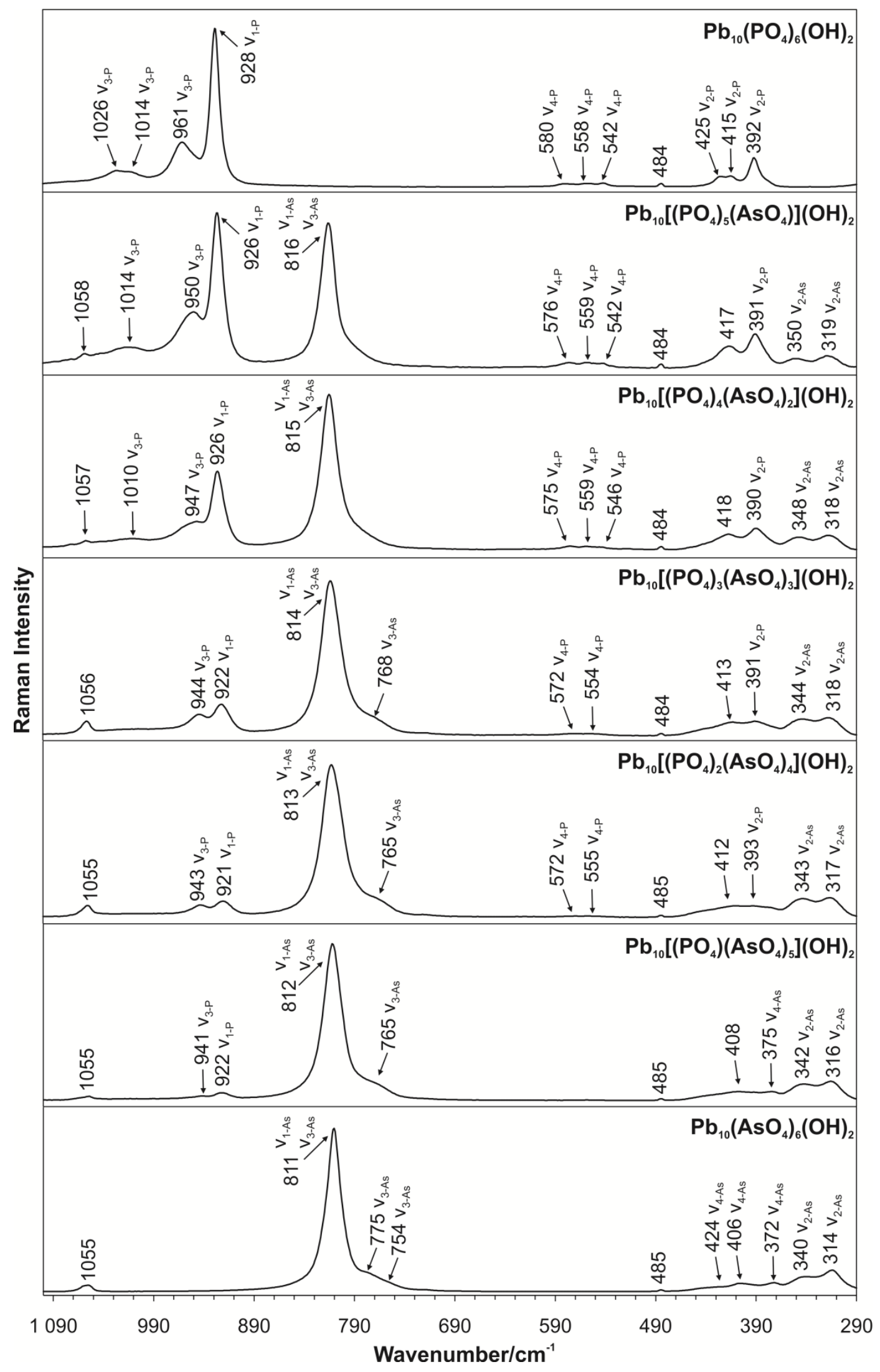

Fig. 2 Average position of the vibrational modes in Raman spectra of HPY-HMI solid solution series in the range between 290 and $1100 \mathrm{~cm}^{-1}$ 
The variations of average positions of the major $\left(\mathrm{AsO}_{4}\right)^{3-}$ and $\left(\mathrm{PO}_{4}\right)^{3-}$ bands, corresponding to the $\mathrm{v}_{1}$ vibrations of $\mathrm{As}-\mathrm{O}$ and $\mathrm{P}-\mathrm{O}$, respectively, are presented in Figure 3. The positions of the bands in all spectra of the series depend on the content of arsenates and phosphates shifting to lower wavenumbers with substitution of $\left(\mathrm{AsO}_{4}\right)^{3-}$ for $\left(\mathrm{PO}_{4}\right)^{3-}$. This shift results from the decreasing bond strength of $\mathrm{X}-\mathrm{O}$ (where $\mathrm{X}=\mathrm{P}, \mathrm{As}$ ) and higher atomic mass of $A s$ than $\mathrm{P}$. The As- $\mathrm{O}$ bond is longer and weaker than $\mathrm{P}-\mathrm{O}$ because of larger ionic radius: $A s^{5+}=0.46 \AA$, while $P^{5+}=0.17 \AA$ [29]. The position of the major $\left(\mathrm{PO}_{4}\right)^{3-}$ band in the spectra of phases containing more than three As atoms per formula unit is determined with the higher uncertainty due to the relatively low intensity of that band in comparison to the intensity of major $\left(\mathrm{AsO}_{4}\right)^{3-}$ band. The changes in intensities of these two bands correlate almost linearly with the chemical composition (Fig. 4). Quantitative determination of peak intensity is, however, sensitive to sample preparation and instrumental settings. Therefore, the ratio of the intensities were determined as potentially less dependent on artifacts. The average ratio of the major band intensities $I_{A s} / I_{P}$ shows strong exponential correlation with increasing As content (Fig. 4). In general, intensity of bands is determined by the change in polarizability during the vibration [41]. The lower polarizability of $\left(\mathrm{PO}_{4}\right)^{3-}$ ion than that of $\left(\mathrm{AsO}_{4}\right)^{3-}$ results in a nonlinear relation between the intensities of bands corresponding to the vibrations of these molecules.

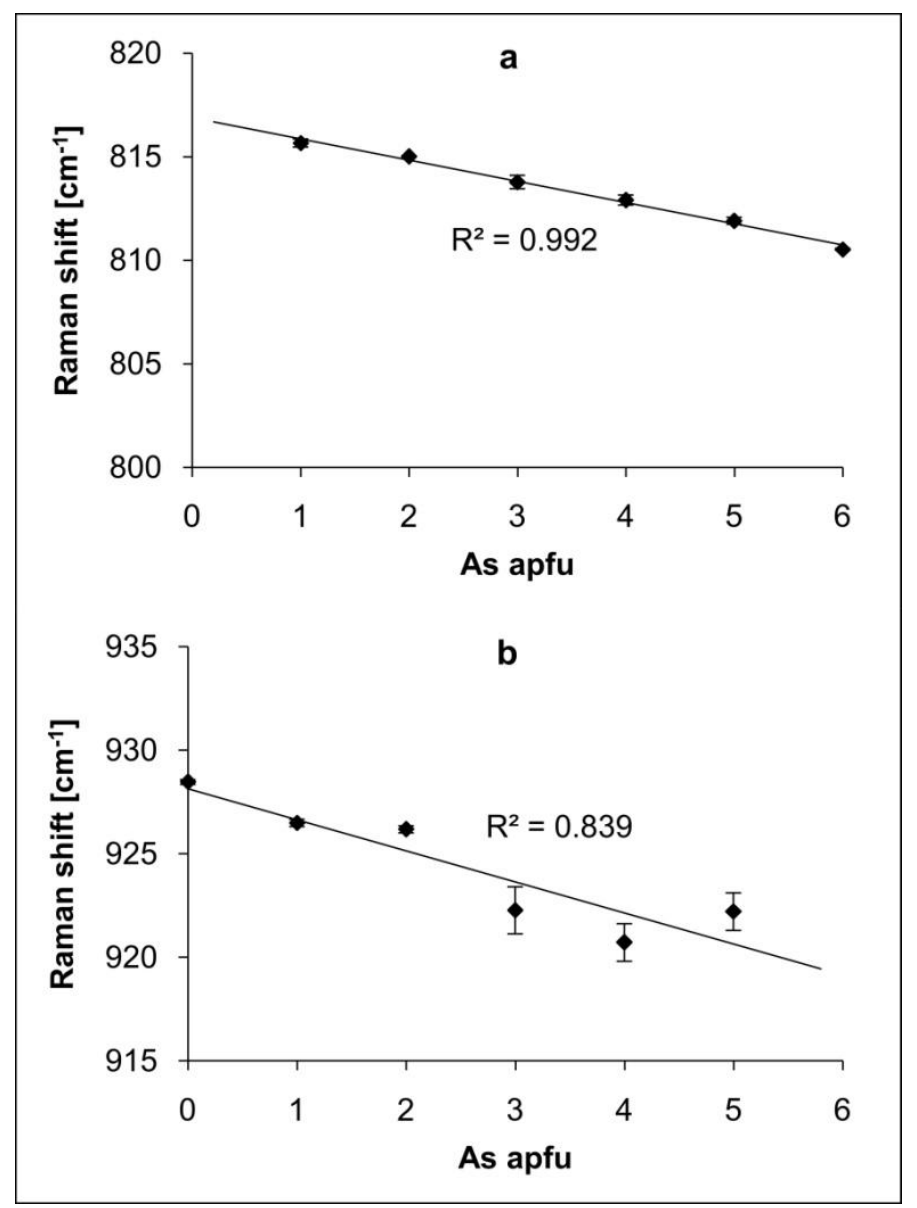


Fig. 3 Systematic variations of average positions of the major $v_{1}$ mode of arsenate (a) and phosphate (b) ions as a function of chemical composition of HPY-HMI solid solution series. Error bars represent 2SD (95\% confidence interval)

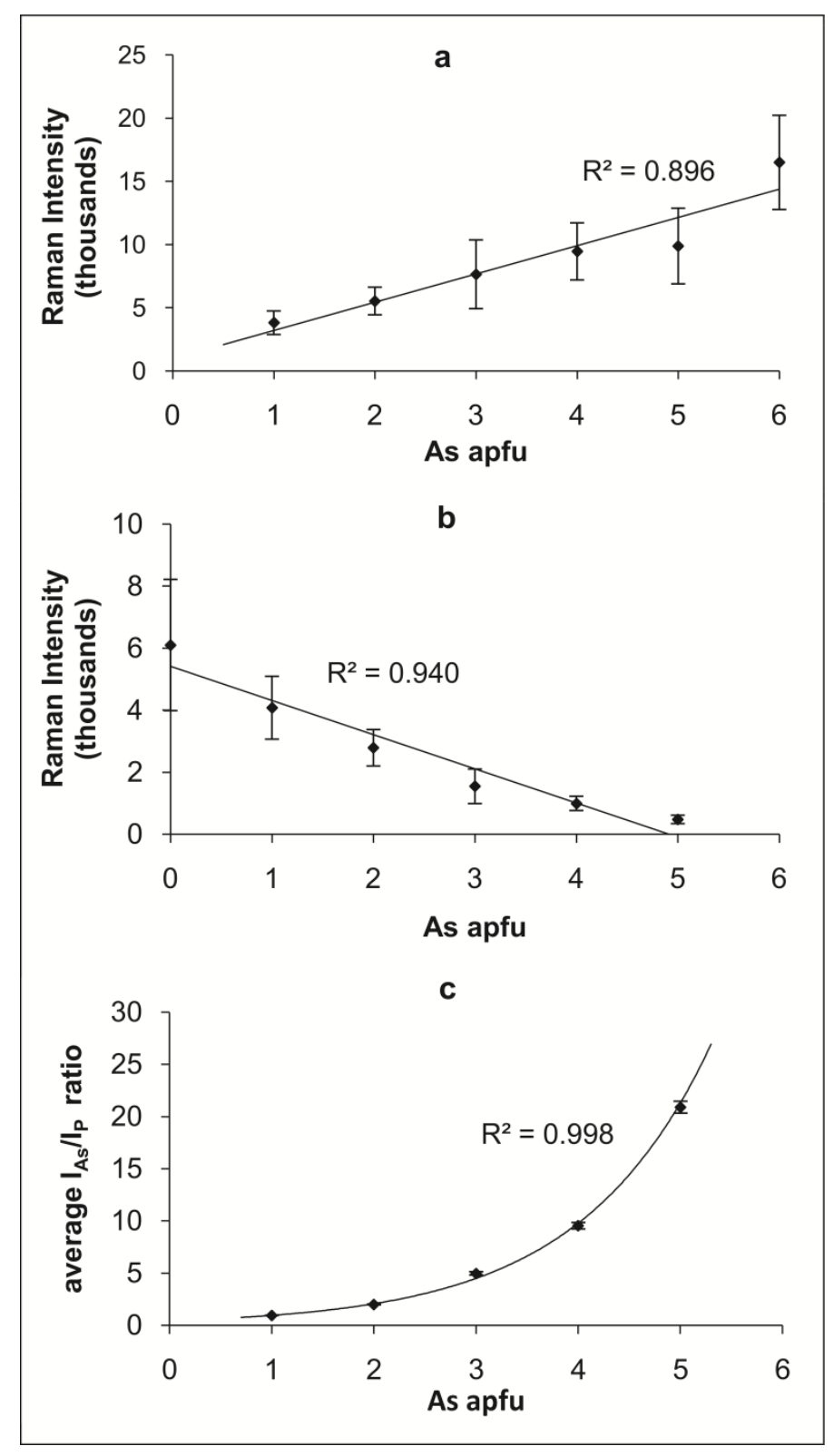

Fig. 4 Systematic variations of average intensity of the major arsenate $v_{1}$ band (a), phosphate $v_{1}$ band (b), and their $I_{A s} I_{P}$ ratio (c) as a function of chemical composition of HPY-HMI solid solution series. Error bars represent 2SD (95\% confidence interval)

The position of the peak attributed to the $(\mathrm{OH})^{-}$mode shifts to the lower wavenumbers from $3565 \mathrm{~cm}^{-1}$ in HPY spectrum to $3556 \mathrm{~cm}^{-1}$ in HMI spectrum (Fig. 5 and 6). In the apatite structure, the hydroxyl ion is located in the channels along the c-axis. It is 
surrounded by other $(\mathrm{OH})^{-}$ions and by $\mathrm{Pb}^{2+},\left(\mathrm{PO}_{4}\right)^{3-}$ and/or $\left(\mathrm{AsO}_{4}\right)^{3-}$. As Hadrich et al. [42] noticed, the $\mathrm{OH} \cdots \mathrm{OH}$ distance is too long for a hydrogen bond. This indicates that the shift of this band with anionic substitution results from interaction of $\mathrm{OH} \cdots \mathrm{O}\left(\mathrm{PO}_{3}\right)$ and $\mathrm{OH} \cdots \mathrm{O}\left(\mathrm{AsO}_{3}\right)$. The substitution of arsenates for phosphates results probably in slight systematic displacement of a hydroxyl anion in the channel. This issue will be addressed in a separate study using high resolution $\mathrm{X}$-ray diffraction data.

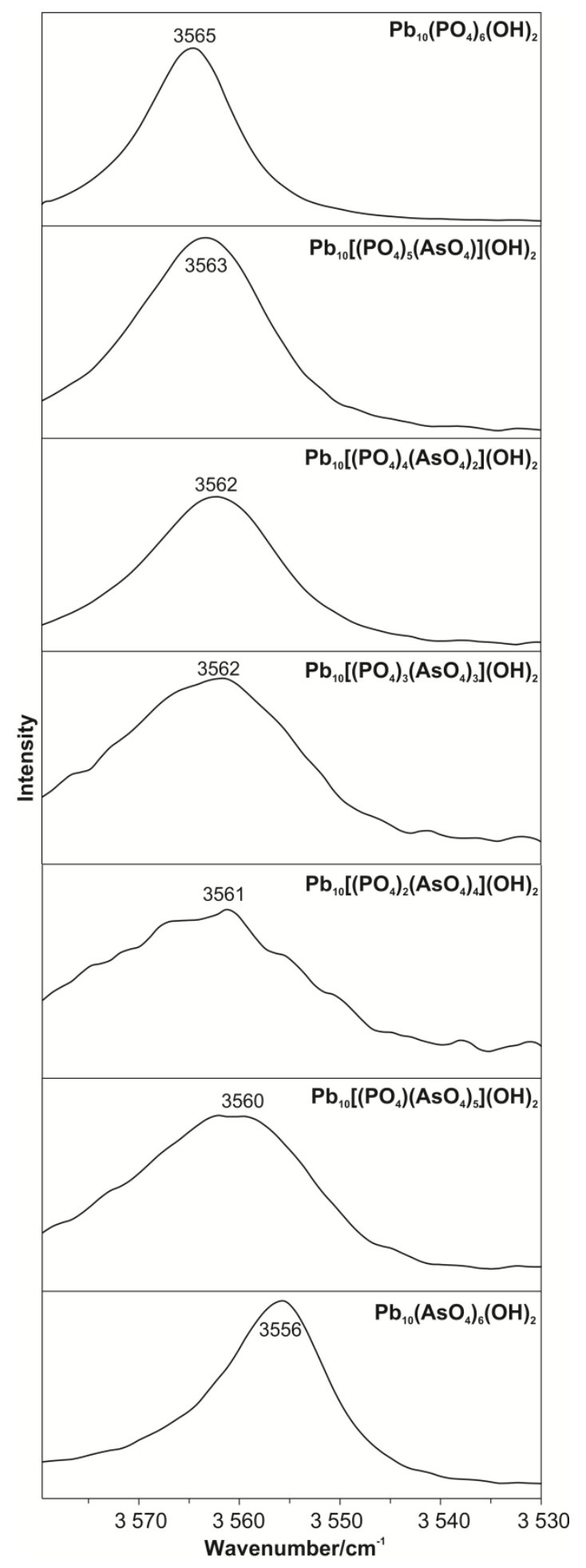


Fig. 5 Average position of the $(\mathrm{OH})^{-}$vibrational mode in Raman spectra of HPY-HMI solid solution series

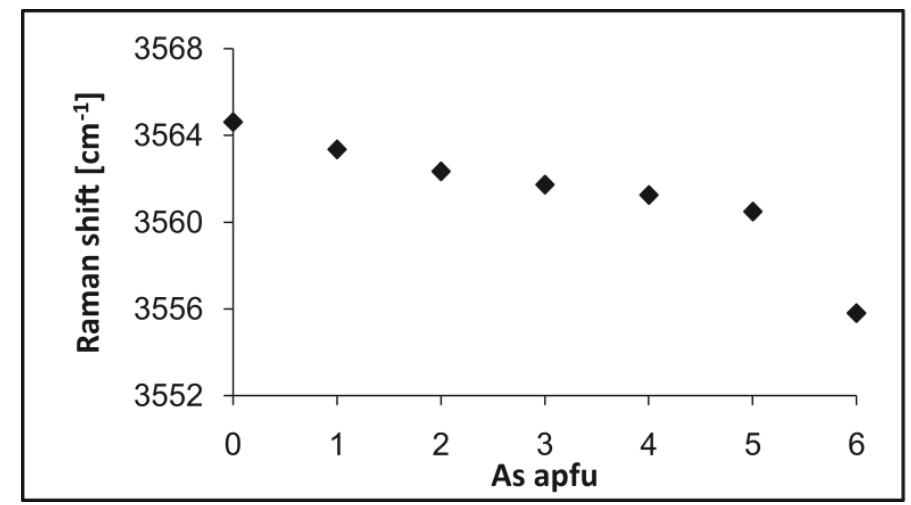

Fig. 6 Variations of average position of the $(\mathrm{OH})^{-}$vibrational mode in Raman spectra of HPY-HMI solid solution series

A very strong coupling between the $v_{1}$ and $v_{3}$ vibrations as well as between $v_{2}$ and $v_{4}$ vibrations causes hiding of some bands. Moreover, the mean values of certain peak positions are established with relatively high standard deviations (up to $6 \mathrm{~cm}^{-1}$ with a $95 \%$ confidence interval) indicating that these bands are composed of two or more split vibrational modes. Therefore, the peak resolve operation for all of the spectra was performed using the Peak Resolve function of the OMNIC software.

The average positions of resolved bands in the range between 700 and $1100 \mathrm{~cm}^{-1}$ are presented as composite patterns in Figure 7 . The antisymmetric stretching vibrations $v_{3}$ of the $\mathrm{P}-\mathrm{O}$ bond are split into four peaks at $950,962,1011$, and $1029 \mathrm{~cm}^{-1}$ in the spectrum of HPY end member, while in the solid solutions a fifth band corresponding to that mode appears at $1029-1042 \mathrm{~cm}^{-1}$. Splitting of the peaks constitute evidence of cancellation of the degeneration whereas the additional band in the intermediate phases indicates even more extended reduction in the symmetry of the phosphate anion due to partial isomorphic substitution by $\left(\mathrm{AsO}_{4}\right)^{3-}$. For the As-O bond, four peaks are observed in the range between 760 and $818 \mathrm{~cm}^{-1}$ in different samples. Further subdivision into $v_{1}$ and $v_{3}$ modes is not well-defined, because even for the isolated $\left(\mathrm{AsO}_{4}\right)^{3-}$ ion, the position of $\mathrm{v}_{1}$ mode coincides with the position of the $v_{3}$ mode. In the analyzed phases, the $v_{3}$ mode splits into three bands and one of them overlaps with the peak of $v_{1}$ vibrations in the range between 802 and $818 \mathrm{~cm}^{-1}$ in various specimens. In the spectrum of $\mathrm{HMI}$ end member, the peaks of the $v_{3}$ mode are discerned at 760 and $775 \mathrm{~cm}^{-1}$. The third band of $v_{3}$ mode overlapping with the peak of the $v_{1}$ mode occurs at $810-811 \mathrm{~cm}^{-1}$. The positions of the resolved peaks may be influenced by the initial settings of OMNIC Peak Resolve operation. This type of 
processing becomes more subjective as the intensity of analyzed band decreases, which particularly affects the $v_{3}$ vibrational modes of $\left(\mathrm{PO}_{4}\right)^{3-}$.
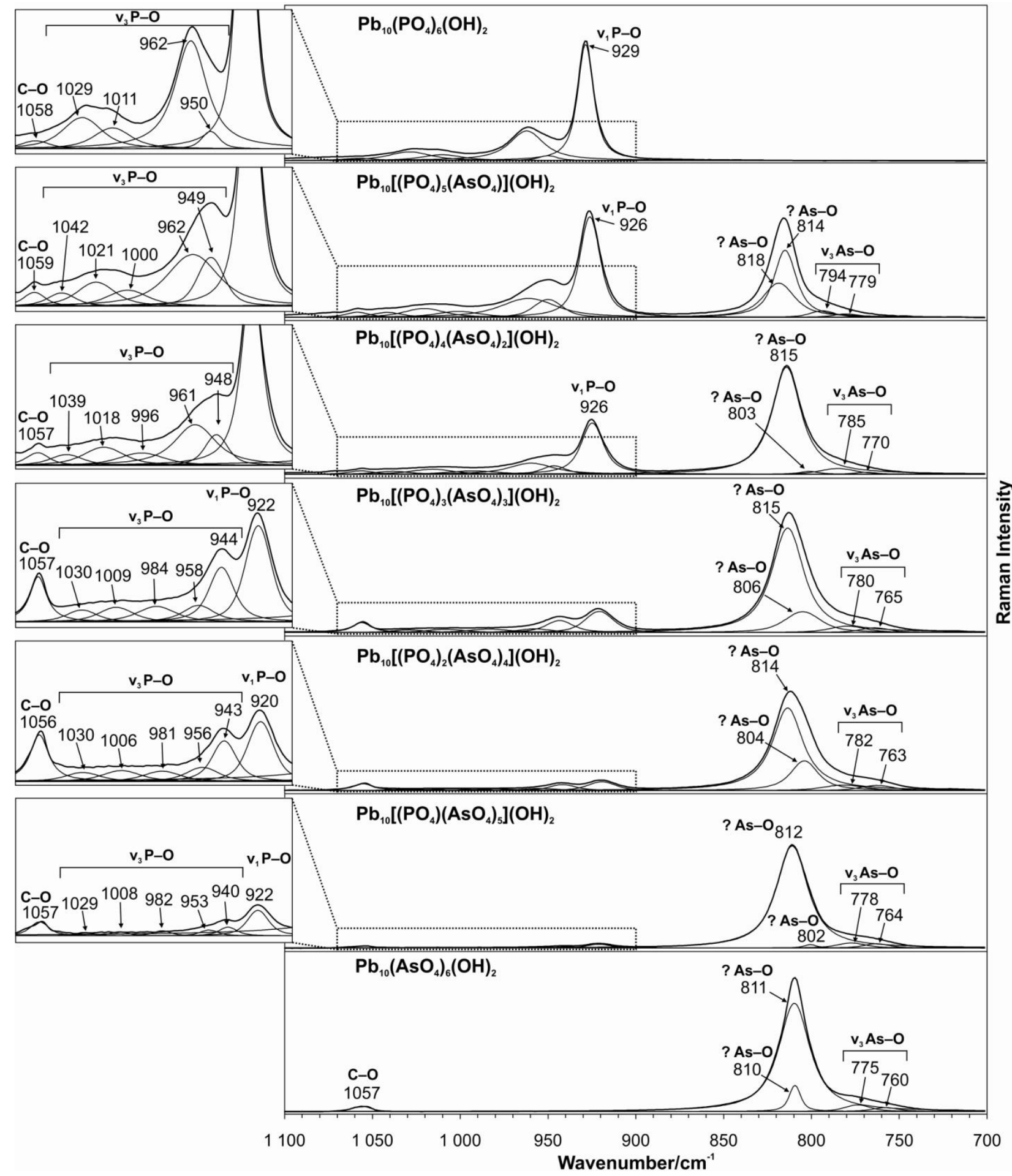

Fig. 7 Results of peak resolve operation of Raman spectra of HPY-HMI series in the range between 700 and $1100 \mathrm{~cm}^{-1}$ 
The variations of the positions of resolved peak with the $95 \%$ confidence interval error bars as a function of chemical composition are shown in Figure 8. Linear correlation for most of them is apparent. In the case of certain peaks (e.g., the $\mathrm{v}_{1}$ mode of $\mathrm{P}-\mathrm{O}$ bond), the variation of Raman shift along the series is small, being at the level of spectral resolution and precision of the method.

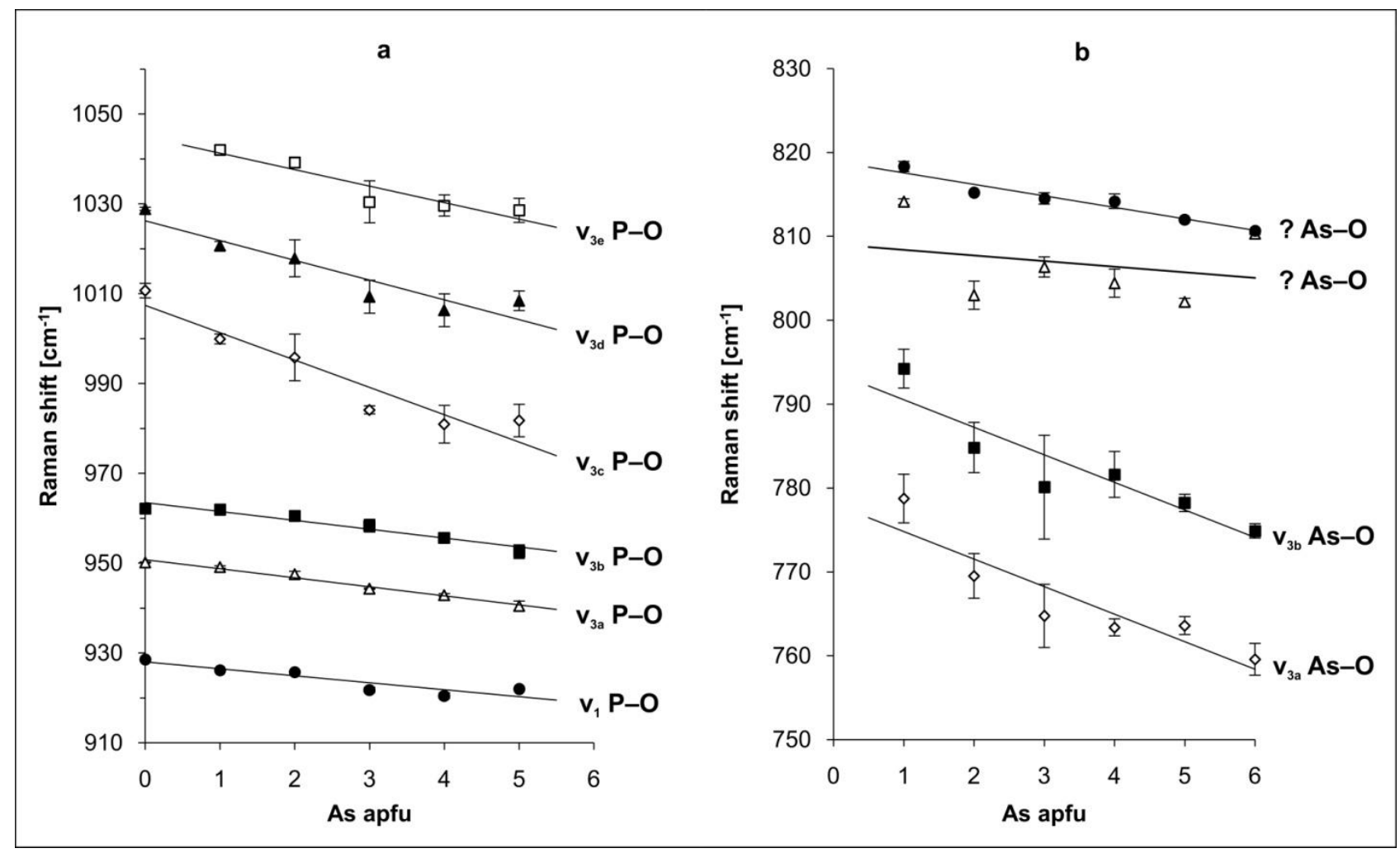

Fig. 8 Systematic variations of the positions of resolved Raman bands in spectra of HPY$\mathrm{HMl}$ series in the range between 700 and $1100 \mathrm{~cm}^{-1}$, corresponding to vibrational modes of phosphate (a) and arsenate (b) ions. Error bars represent 2SD (95\% confidence interval)

Peak resolve operation of Raman spectra in the range between 290 and $700 \mathrm{~cm}^{-1}$ was performed only for the end members (Fig. 9) The bands which correspond to $\mathrm{v}_{2}$ and $\mathrm{v}_{4} \mathrm{O}$ $\mathrm{X}-\mathrm{O}$ angle deformation vibrations (where $\mathrm{X}=\mathrm{P}$ or $\mathrm{As}$ ) coincide with each other and it is not possible to resolve them correctly for solid solutions. The $\mathrm{v}_{2}$ mode of $\left(\mathrm{PO}_{4}\right)^{3-}$ in HPY spectrum splits into four peaks at $542,558,573$, and $582 \mathrm{~cm}^{-1}$, while the $\mathrm{v}_{4}$ vibration splits into five bands at $383,392,402,414$ and $426 \mathrm{~cm}^{-1}$. In HMI spectrum, the subdivision of the $\mathrm{O}-\mathrm{As}-\mathrm{O}$ angle deformation vibrations $\mathrm{v}_{2}$ and $\mathrm{v}_{4}$ is inconclusive due to their very strong coincidence. As regards the existing data of $\mathrm{Cl}$-mimetite [26, 38], additional peaks in 
spectra of $\mathrm{OH}$-mimetite occur at 330 and $445 \mathrm{~cm}^{-1}$. The other bands are observed at 314 , $345,373,389,406$, and $429 \mathrm{~cm}^{-1}$.

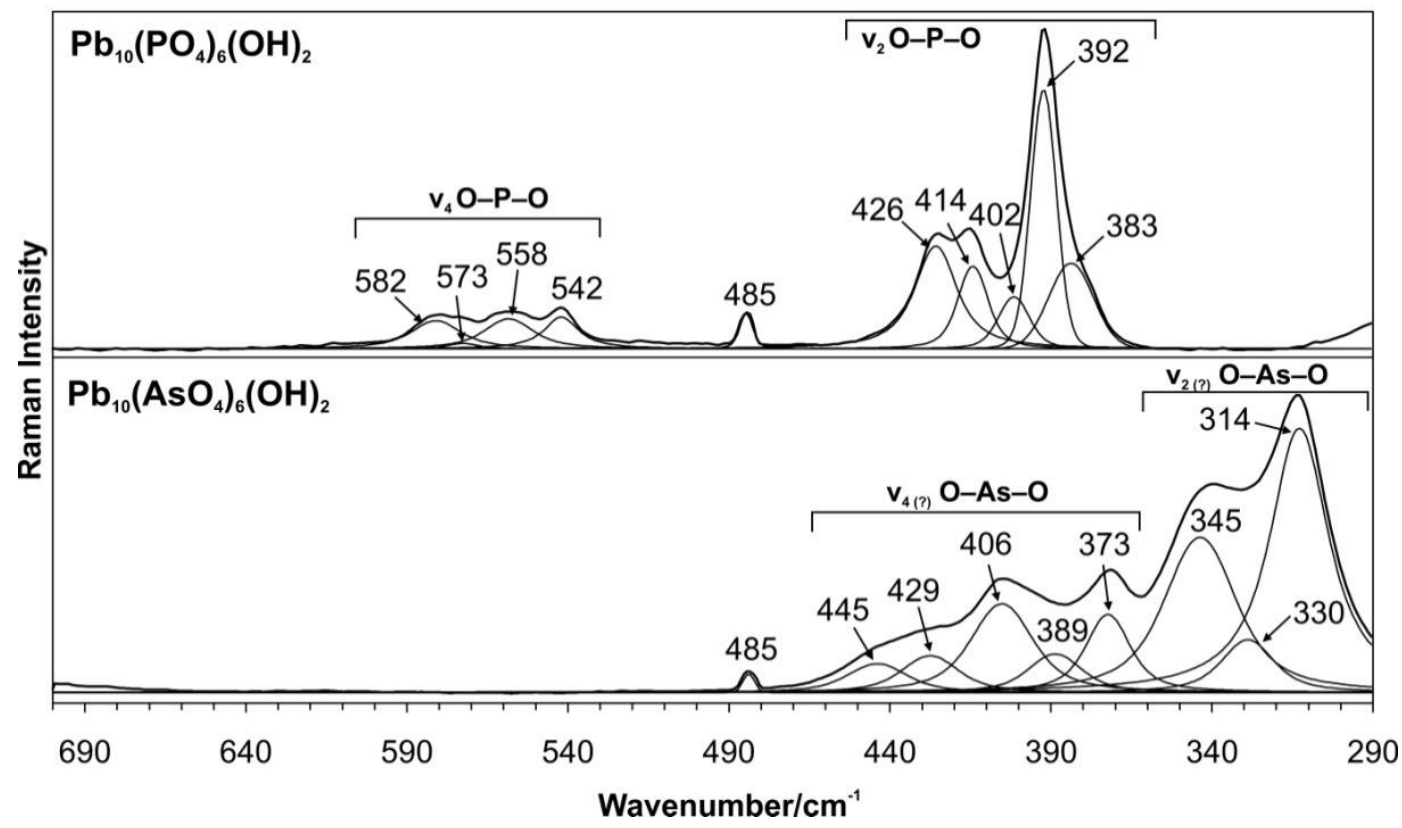

Fig. 9 Results of peak resolve operation of Raman spectra of HPY (upper) and HMI (lower) end members in the range between 290 and $700 \mathrm{~cm}^{-1}$

For the Cl-pyromorphite-Cl-mimetite solid solutions, Bajda et al. [26] reported that the peak positions of the antisymmetric stretching $\left(\mathrm{v}_{3}\right)$ and bending $\left(\mathrm{v}_{4}\right)$ vibrations correlate linearly with the $A s /(A s+P)$ molar ratio. It was also concluded that such correlation might be used to estimate the As and $\mathrm{P}$ content in phases from this series. For hydroxyl analogs of these phases, the peak positions in raw Raman spectra as well as in the resolved ones also vary as a function of chemical composition. The correlation between the positions of major peaks attributed to the $\mathrm{v}_{1}$ modes of $\left(\mathrm{PO}_{4}\right)^{3-}$ and $\left(\mathrm{AsO}_{4}\right)^{3-}$ in raw spectra could be used to estimate the $A s$ and $P$ content. Similar slight variations of the $v_{1}$ vibrations of $\left(\mathrm{PO}_{4}\right)^{3-}$ and $\left(\mathrm{VO}_{4}\right)^{3-}$ correlated with chemical composition of solid solutions between lead fluorapatite and lead fluorvanadate apatite are reported by $\mathrm{He}$ et al. [8]. This confirms that observed changes in band position reflects the chemical composition and cannot be explained by experimental setup or instrument settings. Resolved spectra, however, may be influenced, to some extent, by subjective interpretation. Additionally, the estimation of chemical composition based on the positions of major peaks in raw spectra should be performed with caution due to small variation in Raman shift.

Band assignment to the internal vibrations of the $\left(\mathrm{PO}_{4}\right)^{3-}$ and $\left(\mathrm{AsO}_{4}\right)^{3-}$ molecules in HPY and HMI unresolved Raman spectra collated with band assignment for relevant 
apatites [26, 43-44] is presented in Table 2. The vibrational modes of HPY spectrum are shifted to higher wavenumbers than the vibrations of hydroxyl apatite. This is related to the higher atomic mass of lead atom in $\mathrm{Pb}_{10}\left(\mathrm{PO}_{4}\right)_{6}(\mathrm{OH})_{2}$ than calcium in $\mathrm{Ca}_{10}\left(\mathrm{PO}_{4}\right)_{6}(\mathrm{OH})_{2}$. $\mathrm{A}$ similar effect is observed in the pair $\mathrm{HMI} \mathrm{Pb}_{10}\left(\mathrm{AsO}_{4}\right)_{6}(\mathrm{OH})_{2}$ and johnbaumite $\mathrm{Ca}_{10}\left(\mathrm{AsO}_{4}\right)_{6}(\mathrm{OH})_{2}$. Full vibrational data are not yet available for johnbaumite. The influence of the substitution of $\mathrm{Cl}$ by $\mathrm{OH}$ on vibrational modes of $\left(\mathrm{PO}_{4}\right)^{3-}$ and $\left(\mathrm{AsO}_{4}\right)^{3-}$ is unclear. Furthermore, stronger coupling of $v_{1}$ and $v_{3}$ vibrations is observed on raw Raman spectra for HPY and HMI than for Cl-pyromorphite and Cl-mimetite [26]. Enhancement of the coupling of these vibrations can be associated with broadening of the peaks due to the presence of carbonates in the crystal structure [40]. Moreover, the peak corresponding to the vibrations of carbonate molecules is the least apparent in the spectrum of HPY end member and clearly develops with increasing As content. This may lead to a conclusion that hydroxyl analogs of pyromorphite-mimetite series adopt the $\left(\mathrm{CO}_{3}\right)^{2-}$ ions to a greater extent than chlorine-containing varieties, particularly at the arsenate end of the series. Incorporation of carbonates into the structure of pyromorphite-mimetite solid solution series is the object of the ongoing work [45].

Table 2 Band assignment to the internal vibrations of the $\left(\mathrm{PO}_{4}\right)^{3-}$ and $\left(\mathrm{AsO}_{4}\right)^{3-}$ molecules in HPY and HMl unresolved Raman spectra in comparison to relevant minerals from apatite supergroup

\begin{tabular}{|c|c|c|c|c|c|}
\hline \multirow{2}{*}{ Phase } & \multicolumn{2}{|c|}{$\mathrm{X}-\mathrm{O}$ vibrations $\left[\mathrm{cm}^{-1}\right]$} & \multicolumn{2}{|c|}{$0-X-O$ vibrations $\left[\mathrm{cm}^{-1}\right]$} & \multirow{2}{*}{ References } \\
\hline & $\mathbf{v}_{1}$ & $\mathbf{v}_{2}$ & $\mathbf{v}_{3}$ & $\mathbf{v}_{4}$ & \\
\hline $\begin{array}{l}\text { hydroxylapatite } \\
\mathrm{Ca}_{10}\left(\mathrm{PO}_{4}\right)_{6}(\mathrm{OH})_{2}\end{array}$ & 964 & 433,448 & $\begin{array}{l}\text { 1029, 1034, 1041, } \\
1048,1057,1064 \\
1077\end{array}$ & $580,591,607,614$ & [43] \\
\hline $\begin{array}{l}\text { OH-pyromorphite } \\
\mathrm{Pb}_{10}\left(\mathrm{PO}_{4}\right)_{6}(\mathrm{OH})_{2}\end{array}$ & 928 & $392,415,425$ & $961,1014,1026$ & $542,558,580$ & [this study] \\
\hline $\begin{array}{l}\text { pyromorphite } \\
\mathrm{Pb}_{10}\left(\mathrm{PO}_{4}\right)_{6} \mathrm{Cl}_{2}\end{array}$ & 920 & 393,409 & $945,984,1016,1045$ & $548,553,577$ & [26] \\
\hline $\begin{array}{l}\text { johnbaumite } \\
\mathrm{Ca}_{10}\left(\mathrm{AsO}_{4}\right)_{6}(\mathrm{OH})_{2}\end{array}$ & \multicolumn{2}{|c|}{$830,860,960^{*}$} & & & [44] \\
\hline $\begin{array}{l}\text { OH-mimetite } \\
\mathrm{Pb}_{10}\left(\mathrm{AsO}_{4}\right)_{6}(\mathrm{OH})_{2}\end{array}$ & 811 & 314,340 & $754,775,811$ & $372,406,424$ & [this study] \\
\hline $\begin{array}{l}\text { mimetite } \\
\mathrm{Pb}_{10}\left(\mathrm{AsO}_{4}\right)_{6} \mathrm{Cl}_{2}\end{array}$ & 813 & 315,339 & $736,767,789$ & $372,409,421$ & [26] \\
\hline
\end{tabular}

* only partial data are available for johnbaumite, no band assignment 


\section{Conclusions}

Arsenate substitution in lead hydroxyl apatites is unlimited. Raman spectroscopy applied to this continuous solid solution series of hydroxylpyromorphite $\mathrm{Pb}_{10}\left(\mathrm{PO}_{4}\right)_{6}(\mathrm{OH})_{2}-$ hydroxylmimetite $\mathrm{Pb}_{10}\left(\mathrm{AsO}_{4}\right)_{6}(\mathrm{OH})_{2}$ indicates the systematic changes apparent in the spectra. This method offers a fast and nondestructive analysis of microcrystalline precipitates, natural or synthetic. If used with caution, the correlation of the position or intensities of selected bands may be applied for semiquantitative estimation of chemical composition of lead apatites from this series. This extends the applications of Raman spectroscopy for environmental and engineering problems.

The presence of $\mathrm{CO}_{3}{ }^{2-}$ bands on Raman spectra of all synthetic phases from the series indicates for the first time the incorporation of carbonate ion in lead hydroxyl arsenates. This is despite the fact that the synthesis was performed from aqueous solutions at $80^{\circ} \mathrm{C}$ which minimizes the concentration of carbonate ion dissolved from the air. Even though all the phases from the solid solution series were synthesized at the very same conditions, the relative intensity of the carbonate Raman band increases with As content. This means that $\mathrm{HMI}$ structure exhibits higher affinity for $\left(\mathrm{CO}_{3}\right)^{2-}$ or easily accommodates carbonates than HPY structure. There is no doubt that lead apatites precipitating at ambient conditions from natural solutions will form in the presence of much higher concentrations of $\left(\mathrm{CO}_{3}\right)^{2-}$. Therefore, the effect of carbonates on the structure and thermodynamic stability of these phases (HMI in particular) needs to be investigated.

This work was supported by Polish NCN grant No. 2011/01/M/ST10/06999 and partly by US NSF grant EAR-0952298 to JR.

[1] Q.Y. Ma, S.J. Traina, T.J. Logan, J.A. Ryan, Environ. Sci. Technol. 27 (1993) 1803.

[2] L.G. Twidwell, J. McCloskey, Technologies and potential technologies for removing arsenic from process and mine wastewater, in: I. Gaballah, J. Hager, R. Solozabal (Eds.), Proceedings, Global Symposium on Recycling, Waste Treatment and Clean Technology, TMS, Warrendale, Pennsylvania, 1999, pp. 1715-26.

[3] T. Bajda, E. Szmit, M. Manecki, Removal of $A s(V)$ from solutions by precipitation of mimetite $\mathrm{Pb}_{5}\left(\mathrm{AsO}_{4}\right)_{3} \mathrm{Cl}$, in: L. Pawłowski, M.R. Dudzińska, A. Pawłowski (Eds.), Environmental Engineering, Taylor \& Francis Group, London, 2007, pp. 119-124. 
[4] M.C.F. Magalhães, P.A. Williams, Apatite Group Minerals: Solubility and Environmental Remediation, in: T.M. Letcher (Eds.), Thermodynamics, Solubility and Environmental Issues, Elsevier, Amsterdam, 2007, pp. 327-342.

[5] X. Liu, S.R. Shieh, M.E. Fleet, A. Akhmetov, Am. Miner. 93 (2008) 1581.

[6] P. Miretzky, A. Fernandez-Cirelli, Environ. Chem. Lett. 6 (2008) 121.

[7] M.E. Fleet, X. Liu, S.R. Shieh, Phys. Chem. Miner. 37 (2010) 1.

[8] Q. He, X. Hu, S. Li, H. Wang, Phys. Chem. Miner. 38 (2011) 741.

[9] X. Liu, M.E. Fleet, S.R. Shieh, Q. He, Phys. Chem. Miner. 38 (2011) 397.

[10] T. Marchlewski, J. Rakovan, Geochim. Cosmochim. Acta 74 (2010) Supplement 1 A667.

[11] Q. He, X. Liu, X. Hu, L. Deng, Z. Chen, B. Li, Y. Fei, Phys. Chem. Miner. 39 (2012) 219.

[12] G. Engel, Naturwissenschaften 57 (1970) 355.

[13] G. Engel, W.E. Klee, J. Solid State Chem. 5 (1972) 28.

[14] G. Engel, J. Solid State Chem. 6 (1973) 286.

[15] R.M.H. Verbeeck, C.J. Lassuyt, H.J.M. Heijliers, F.C.M. Driessens, J.W.G.A. Vrolijk, Calcif. Tissue Int. 33 (1981) 243.

[16] S.V.C. Rao, J. Indian Chem. Soc. 52 (1975) 1107.

[17] S.V.C. Rao, J. Indian Chem. Soc. 53 (1976) 587.

[18] S.V.C. Rao, J. Indian Chem. Soc. 53 (1976) 349.

[19] S.V.C. Rao, J. Indian Chem. Soc. 53 (1976) 352.

[20] J.C. Elliott, R.M. Wilson, S.E.P. Dowker, Advances in X-ray Analysis 45 (2002) 172.

[21] Y. Pan, M.E. Fleet, Rev. Mineral. Geochem. 48 (2002) 13.

[22] M. Pasero, A.R. Kampf, C. Ferraris, I.V. Pekov, J. Rakovan, T.J. White, Eur. J. Mineral. 22 (2010) 163.

[23] C. Rey, C. Combes, C. Drouet, H. Sfihi, Adv. Sci. Tech. 49 (2006) 27.

[24] R.C. Smith, Mineral Resources Report No. 72, Pennsylvania Geological Survey, 1977.

[25] G. Markl, M.A.W. Marks, J. Holzäpfel, T. Wenzel, Am. Mineral. 99 (2014) 1133.

[26] T. Bajda, W. Mozgawa, M. Manecki, J. Flis, Polyhedron 30 (2011) 2479.

[27] M. Kwaśniak-Kominek, J. Matusik, T. Bajda, M. Manecki, J. Rakovan, T. Marchlewski, B. Szala, Fourier transform infrared spectroscopic study of hydroxyl analogs of pyromorphite and mimetite solid solutions series, Polyhedron, in revision 
[28] M. Fries, A. Steele, Raman spectroscopy and confocal Raman imaging in mineralogy and petrography, in: T. Dieing, O. Hollricher, J. Toporski (Eds.), Confocal Raman Microscopy, Springer-Verlag, Berlin, 2010, pp. 111-135.

[29] J. Flis, O. Borkiewicz, T. Bajda, M. Manecki, J. Klasa, J. Synchrotron Radiat. 17 (2010) 207.

[30] B. Badraoui, A. Aissa, A. Bigi, M. Debbabi, M. Gazzano, J. Solid State Chem. 179 (2006) 3065.

[31] Y. Zhu, X. Zhang, F. Long, H. Liu, M. Qian, N. He, Mater. Lett. 63 (2009) 1185.

[32] J. L. Jambor, J.E. Dutrizac, Can. Mineral. 33 (1995) 1063.

[33] S.D. Ross, Inorganic Infrared and Raman Spectra, McGraw-Hill Book Company, London, 1972.

[34] K. Nakamoto, Infrared and Raman Spectra of Inorganic and Coordination Compounds, Theory and Applications in Inorganic Chemistry, Wiley, Hoboken, New Jersey, 2009.

[35] S.R. Levitt, R.A. Condrate, Am. Mineral. 55 (1970) 1562.

[36] D.M. Adams, I.R. Gardner, J. Chem. Soc. Dalton Trans. 14 (1974) 1505.

[37] G. Bartholomäi, W.E. Klee, Spectrochim. Acta Part A 34 (1978) 831.

[38] R.L Frost, J.M. Bouzaid, S. Palmer, Polyhedron 26 (2007) 2964.

[39] R.L Frost, S. Palmer, Polyhedron 26 (2007) 4533.

[40] M.P. Sternlieb, J.D. Pasteris, B.R. Williams, K.A. Krol, C.H. Yoder, Polyhedron 29 (2010) 2364.

[41] D.W. Mayo, F.A. Miller, R.W. Hannah, Course notes on the interpretation of infrared and Raman spectra, Wiley, Hoboken, New Jersey, 2003.

[42] A. Hadrich, A. Lautié, T. Mhiri, J. Raman Spectrosc. 32 (2001) 33.

[43] G. Penel, G. Leroy, C. Rey, E. Bres, Calcif. Tissue Int. 63 (1998) 475.

[44] L.G. Crimmins, Structure and Chemistry of Minerals in the $\mathrm{Ca}-(\mathrm{As}, \mathrm{P})-(\mathrm{OH}, \mathrm{F}, \mathrm{Cl})$ Apatite System: Johnbaumite, Svabite, and Turneaureite from Franklin and Sterling Hill, New Jersey, USA. Diss. Miami University, 2012.

[45] M. Kwaśniak, M. Manecki, M. Lempart, T. Bajda, J. Matusik, European Mineralogical Conference Abstract, EMC 2012-723, 2012. 